\title{
Pengaruh Bimbingan Belajar Terhadap Kemandirian Belajar Siswa SDN 025 Rambah Hilir
}

\author{
Joko Wahono* \\ * Sekolah Dasar Negeri 025 Rambah Hilir, Rokan Hilir \\ joko.wahono@gmail.com
}

\begin{tabular}{l} 
INFO ARTIKEL \\
\hline Riwayat Artikel: \\
Diterima: 12 Oktober 2018 \\
Disetujui: 25 Juni 2019 \\
\end{tabular}

\section{Kata kunci:}

Bimbingan Belajar

Kemandirian Belajar

Bimbingan Konseling

\section{Alamat Korespondensi:}

\begin{abstract}
This study discusses two variables, namely tutoring and student learning independence. The population taken in this study were all grade IV students at 025 Elementary School in Rambah Hilir Academic Year 2013/2014, totaling 31 students. Because the total population is less than 100, in this study the number of students taken from class IV in SD Negeri 025 Rambah Hilir in the 2013/2014 Academic Year, amounting to 31 students were taken as samples in this study. This type of research is pre-experiment (not real experiment) or quasi experiment. Researchers used one group pre-test and post-test design. Based on the results of the study that that tutoring has an average of 49.68 while the variable students' learning independence has an average of 59.03. In addition, it is known that the value of t-test is 4.733 while the magnitude of 0.007 is less than 0.05 . Thus, $\mathrm{HO}$ is rejected, which means there is an influence of tutoring on the learning independence of elementary school students 025 Rambah Hilir, Rokan Hulu Regency, Riau Province. While the coefficient of determination is 0.324 implies that the influence of the variable of tutoring on student learning independence is $32.4 \%$. While $67.6 \%$ is influenced by other variables.
\end{abstract}

ABSTRAK

\begin{abstract}
Abstrak: Penelitian ini membahas dua variabel, yaitu bimbingan belajar dan kemandirian belajar siswa. Populasi yang diambil dalam penelitian ini adalah seluruh siswa kelas IV di SD Negeri 025 Rambah Hilir Tahun Pelajaran 2013/2014, berjumlah 31 siswa. Karena jumlah populasi kurang dari 100, maka pada penelitian ini jumlah siswa diambil dari kelas IV di SD Negeri 025 Rambah Hilir Tahun Pelajaran 2013/2014, berjumlah 31 siswa yang diambil sebagai sampel dalam penelitian ini. Jenis penelitian ini adalah pre experiment (eksperiment tidak sebenarnya) atau quasi experiment. Peneliti menggunakan one group pretest and post-test design. Berdasarkan hasil penelitian bahwa bahwa bimbingan belajar memiliki rata-rata 49,68 sedangkan variabel kemandirian belajar siswa memiliki rata-rata 59,03. Selain itu, diketahui besarnya nilai t tes adalah 4,733 sedangkan besarnya signifikansi 0,007 lebih kecil dari 0,05. Dengan demikian, $H_{0}$ ditolak yang berarti ada pengaruh bimbingan belajar terhadap kemandirian belajar siswa SD Negeri 025 Rambah Hilir Kabupaten Rokan Hulu Provinsi Riau. Sedangkan besar koefisien determinasi adalah 0,324 mengandung pengertian bahwa pengaruh variabel bimbingan belajar terhadap kemandirian belajar siswa adalah 32,4\%. Sedangkan 67,6\% dipengaruh oleh variabel lain.
\end{abstract}

Joko Wahono,

Sekolah Dasar Negeri 025 Rambah Hilir, Rokan Hilir

Email: joko.wahono@gmail.com

\section{LATAR BELAKANG}

Dalam keseluruhan proses pendidikan di sekolah, kegiatan belajar merupakan kegiatan yang paling pokok. Ini berarti bahwa berhasil tidaknya pencapaian tujuan pendidikan banyak tergantung pada bagaimana proses belajar yang dialami oleh siswa sebagai anak didik. Belajar adalah tahapan perubahan seluruh tingkah laku individu yang relatif menetap sebagai hasil pengalaman dan interaksi dengan lingkungan yang menitik beratkan proses kognitif (Syah, 1999). Kemandirian belajar merupakan salah satu faktor yang menentukan keberhasilan siswa dalam belajar, sehingga sikap mandiri ini penting dimiliki oleh siapa saja yang ingin mencapai kesuksesan dalam hidupnya. Orang tua mempunyai peranan yang sangat penting dalam membentuk kemandirian pada diri anak-anaknya, termasuk 
dalam kemandirian belajar. Hal ini disebabkan karena orang tualah yang menjadi pendidik pertama dan utama. Dengan kata mlain, orang tua menjadi penanggung jawab pertama dan utama terhadap pendidikan anak-anaknya.

Hubungan pembinaan dengan kemandirian belajar ada pada pola pembinaan orang tua ketika memberikan arahan bagi anak-anaknya untuk memiliki sikap yang tidak mudah terpengaruh oleh orang lain, mampu menemukan apa yang harus dilakukan dan bisa memecahkan permasalahannya sendiri tanpa bantuan orang lain. Faktor selain lingkup keluarga yaitu lingkungan sekolah yang berperan aktif di dalamnya yaitu guru. Dengan kata lain guru menjadi penanggung jawab kedua setelah orang tua terhadap pendidikan anak-anaknya. Di sisi lain masa anak-anak adalah masa yang penuh tantangan akibat terjadinya perkembangan-perkembangan yang disebabkan oleh adanya pertumbuhan baik fisik, mental, emosi, kepribadian dan lain sebagainya sesuai dengan tingkat perkembangan usia anak. Anak akan mengalami masa remaja. Umur remaja adalah umur peralihan dari anak menjelang dewasa, yang merupakan masa perkembangan terakhir bagi pembinaan kepribadian atau masa persiapan untuk memasuki umur dewasa, problemnya tidak sedikit (Daradjat, 1991).

Arahan dan pendidikan yang diberikan kepada siswa dimaksudkan agar mereka dapat mengembangkan potensi dan kemampuan yang dimiliki secara totalitas, sehingga nantinya akan menjadi manusia yang berkualitas tinggi serta mencapai kedewasaan yang sempurna. Beberapa ciri yang harus dimiliki oleh orang yang sudah dewasa antara lain: dia dapat berfikir sehat dan maju, bersikap fleksibel, dapat bekerja secara efektif dan efisien, dapat berdiri dan bertanggung jawab sendiri dan lain-lain (Suhartin C, 1986). Orang yang sudah dewasa akan percaya diri dan akan mampu menerima tanggung jawab. Ia mempunyai pendirian, tidak ikut-ikutan dan seandainya ia mengikuti pendapat orang lain, maka ia akan mengikutinya dengan pertimbangan yang matang. Apabila ia mendapatkan masalah yang sulit ia akan menyelesaikannya dengan tepat, bijaksana dan masuk akal. Beberapa hal tersebut merupakan contoh dari sikap mandiri yang merupakan ciri mendasar dari kedewasaan. Perilaku mandiri adalah perilaku memelihara hakekat eksistensi diri (Ali dan Asrori, 2006). Sikap kemandirian seperti ini, perlu ditanamkan pada diri siswa sejak dini. Hal ini dilakukan dalam rangka mengembangkan sikap yang dapat berdiri sendiri sehingga anak akan tumbuh menjadi pribadi yang mampu berinisiatif, penuh kreatifitas, disiplin dan bertanggung jawab. Pada akhirnya, siswa diharapkan mampu mengatasi semua permasalahan hidupnya di masa sekarang dan di masa yang akan datang dengan kekuatannya sendiri tanpa meminta bantuan dari orang lain, serta mempunyai keberanian dalam mengambil keputusan dengan penuh rasa tanggung jawab.

Hasil observasi yang dilakukan oleh peneliti juga didapatkan data bahwa motivasi dan kemandirian belajar pada siswa dalam mendapatkan ilmu melalui proses pembelajaran masih kurang, hal ini dibuktikan dengan ketika proses pembelajaran ada siswa yang kurang responsive dan bersikap cuek, ketika diberikan tugas, mereka selalu memberikan alasan sudah terlalu banyak tugas yang diberikan, ketika diberikan kisi-kisi ujian, siswa bukannya termotivasi untuk belajar melainkan digunakan untuk bahan membuat contekan, ketika praktek skills lab siswa kurang antusias untuk berusaha mencoba, ketika diberikan waktu untuk mandiri hanya beberapa siswa yang menggunakan kesempatan tersebut akibatnya mereka mendapatkan nilai ujian yang kurang bagus dan banyak yang mengikuti ujian remedial skills lab. Selain itu, juga pelaksanaan bimbingan oleh guru BK juga jarang dilakukan. Hal ini mungkin disebabkan oleh tidak adanya protap bagi pelaksanaan bimbingan guru BK. Berdasarkan gejala tersebut, guru perlu memiliki kreatifitas untuk mendorong siswanya agar tetap rajin belajar, mengerjakan tugas tepat waktu serta aktif bertanya saat guru menjelaskan materi pelajaran. Upaya yang diperlukan untuk mengatasi permasalahan kemandirian belajar siswa adalah mengoptimalkan layanan bimbingan dan konseling kepada siswa. Salah satunya pemberian bantuan / bimbingan melalui layanan bimbingan belajar.

Bimbingan belajar adalah kegiatan konsultasi antara guru pembimbing dengan siswa dalam merencanakan studi serta membantu menyelesaikan masalah studi yang dialami, agar siswa yang bersangkutan dapat menyelesaikan studinya dengan baik sesuai dengan minat dan kemampuannya. Bimbingan belajar juga diartikan sebagai bimbingan yang diarahkan untuk membantu para siswa dalam menghadapi dan memecahkan masalah masalah akademik diantaranya yaitu pengenalan kurikulum, pemilihan jurusan, cara belajar, penyelesainan tugas-tugas dan latihan, pencarian dan penggunaan sumber-sumber belajar, perencanaan pendidikan lanjutan. Bimbingan belajar bertujuan untuk membantu siswa dalam menghadapi dan memecahkan masalah-masalah dalam bidang pendidikan pada khususnya. Sebagaimana telah diungkapkan di depan bahwa bimbingan belajar berkaitan dengan kegiatan pendidikan, maka persoalan yang muncul terutama dari siswa sendiri sebagai siswa seperti pengaturan waktu belajar yang efektif, memilih metode belajar yang tepat, menggunakan buku-buku pelajaran bahasa inggris, cara belajar dalam kelompok, mempersiapkan ujian, memilih mata pelajaran yang cocok dan sebagainya. Sesuai dengan hal tersebut maka bimbingan belajar memberikan bantuan kepada mahasiswa dalam hal kesulitan dalam belajar sehingga dapat meningkatkan kemandirian belajar siswa.

Bimbingan belajar menurut Dewa Ketut Sukardi (2002: 40) adalah bimbingan dalam hal menemukan cara belajar yang tepat, dalam memilih program studi yang sesuai, dan dalam mengatasi kesukaran-kesukaran yang timbul berkaitan dengan tuntutan-tuntutan belajar di suatu institusi pendidikan. Sedangkan menurut Sukmadinata (2005) mengemukakan bahwa bimbingan belajar merupakan salah satu teknik pemberian bantuan secara individual dan secara langsung berkomunikasi. Dalam hal ini pemberian bantuan dilakukan dengan hubungan yang bersifat face to 
face relationship (hubungan empat mata) yang dilakukan dengan wawancara antara counselor dengan kasus. Lebih lanjut menurut Hamalik (2004) mengemukakan bahwa bimbingan belajar adalah bimbingan yang ditunjukan kepada siswa untuk mendapat pendidikan yang sesuai dengan kebutuhan, bakat, minat, dan kemampuannya dan membantu siswa untuk menentukan cara-cara yang efektif dan efesien dalam mengatasi masalah belajar yang dialami oleh siswa. Menurut Abu Ahmadi, (1991). Bimbingan belajar adalah suatu proses pemberian bantuan terus-menerus dan sistematis kepada individu atau peserta didik dalam memecahkan masalah yang dihadapinya yang kaitannya dengan kegiatan belajar. Berdasarkan beberapa definisi di atas maka dapat disimpulkan bahwa bimbingan belajar adalah suatu proses pemberian bantuan kepada siswa dalam menyelesaikan masalah-masalah belajar yang dihadapi siswa, sehingga tujuan dari belajar akan tercapai.

Dalam bimbingan belajar ini klien yang di hadapi bukanlah bersifat individual tetapi terdiri dari beberapa orang yang akan bersama-sama memanfaatkan dinamika individu untuk memebahas topik/ permasalahan dan belajar untuk lebih mengembangkan dirinya termasuk mengembangkan kemandirian belajar mereka. Dengan adanya hubungan yang interaktif tersebut akan merasa lebih mudah dan leluasa karena merupakan teman sebaya mereka sendiri. Selain itu, dengan melakukan bimbingan belajar yang memanfaatkan dinamika kelompok ini, siswa juga belajar untuk memahami dan mengendalikan diri sendiri, memahami orang lain, saling bertukar pendapat tentang minat belajar. Fenomena ini dapat dimaknai sebagai petunjuk yang mengandung implikasi bahwa interaksi dan dinamika yang tumbuh dalam bimbingan belajar diharapkan dapat digunakan untuk meningkatkan kemandirian belajar siswa. Dengan demikian, dapat disimpulkan bahwa hubungan antara bimbingan belajar dan kemandirian belajar adalah bimbingan belajar merupakan faktor eksternal dari kemandirian belajar. Tujuan bimbingan belajar tersebut secara umum adalah untuk meningkatkan minat belajar. Apabila bimbingan kelompok ini menurut persepsi siswa bermanfaat, maka bimbingan belajar yang diberikan diharapkan dapat memberikan kontribusi terhadap peningkatan kemandirian belajar siswa.

Dari uraian di atas penulis mengajukan hipotesis kerja bahwa bimbingan belajar efektif untuk meningkatkan kemandirian belajar siswa SD Negeri 025 Rambah Hilir Kabupaten Rokan Hulu Provinsi Riau.

\section{METODE}

Jenis penelitian ini adalah pre experiment (eksperiment tidak sebenarnya) atau quasi experiment. Peneliti menggunakan one group pre-test and post-test design karena tidak ada perbandingan dengan kelompok kontrol, sehingga satu kelompok tes diberikan satu perlakuan yang sama sebelum dan sesudah mendapatkan perlakuan tertentu. Dalam penelitian ini yang menjadi populasi penelitian adalah seluruh siswa kelas IV di SD Negeri 025 Rambah Hilir Tahun Pelajaran 2013/2014, berjumlah 31 siswa. Sampel adalah sebagian atau wakil populasi yang diteliti, Arikunto (2006: 131) menyarankan jika jumlah subyeknya kurang dari 100, lebih baik diambil semua sehingga penelitiannya penelitian populasi. Selanjutnya jika jumlah subjeknya besar dapat diambil sampel antara $10-15 \%$ atau $20-25 \%$ atau lebih, tergantung setidak-tidaknya dari kemampuan peneliti dilihat dari waktu, tenaga, dan dana, sempit luasnya wilayah pengamatan dari subyek karena hal ini menyangkut banyak sedikitnya data, besar kecilnya resiko yang ditanggung oleh peneliti. Untuk penelitian yang resikonya besar, tentu saja jika sampelnya besar akan lebih baik. Karena jumlah populasi kurang dari 100, maka pada penelitian ini jumlah siswa diambil dari kelas IV di SD Negeri 025 Rambah Hilir Tahun Pelajaran 2013/2014, berjumlah 31 siswa yang diambil sebagai sampel dalam penelitian ini. Pengumpulan data dalam penelitian ini menggunakan dua jenis metode, yaitu: metode angket dan metode dokumentasi. Analisis data yang digunakan adalah analisis deskriptif dan analisis inferensial. Analisis deskriptif digunakan untuk menentukan besar rata- rata (Mean), distribusi frekuensi, dan pembuatan histogram dari variabel penelitian yang mencakup bimbingan belajar dan kemandirian belajar siswa SD Negeri 025 Rambah Hilir Kabupaten Rokan Hulu. Analisis inferensial pada penelitian ini dilakukan dengan tujuan agar prestasi penelitian dapat dibuat kesimpulan pengujian hipotesis secara generalisasi. Untuk mengetahui pengaruh yang signifikan antara bimbingan belajar terhadap kemandirian, maka data yang telah ada akan dianalisis dengan menggunakan rumus regresi linear sederhana. Sebelum melakukan analisis data ada syarat yang harus dilakukan, yaitu: uji normalitas dan uji homogenitas.

\section{HASIL}

\section{Deskripsi Data Penelitian}

Data variabel bimbingan belajar dalam penelitian ini dikumpulkan melalui penyebaran kuesioner kepada 31 orang responden. Pertanyaan yang diajukan dalam variabel berjumlah 20 item pertanyaan. Distribusi skor jawaban responden menyebar dari skor terendah 41 dan skor tertinggi 59. Berdasarkan perhitungan dari distribusi data, diperoleh rata-rata sebesar 49,68 dan standar deviasi (SD) 4,230. Perhitungan ini menunjukkan rata-rata dan median yang tidak jauh berbeda. Hal ini memberikan indikasi bahwa skor data variabel kemandirian belajar cenderung berdistribusi normal. Sutrisno Hadi menyebutkan bahwa, harga rata-rata yang tidak jauh berbeda dengan harga median, dapat dipakai sebagai ukuran gejala pusat untuk kepentingan analisis selanjutnya (Sutrisno Hadi, 1998:51- 
55). Kesimpulan serupa juga diperoleh jika data yang sama dianalisa melalui uji skewness $(0,325)$ dan kurtosis (0,105), dan ternyata jauh berada dibawah angka standar yang ditetapkan angka tiga. Hasil perhitungan ini memberikan indikasi bahwa data variabel bimbingan belajar berdistribusi normal. Sebaran skor bimbingan belajar guru disajikan dalam daftar distribusi frekuensi dengan jumlah kelas sebanyak 5 dan panjang kelas 4. Deskripsi data secara lengkap dapat dilihat pada lampiran tesis ini. Gambaran umum variabel bimbingan belajar ini bila ditampilkan dalam bentuk grafik histogram dapat dilihat pada tampilan di bawah ini.

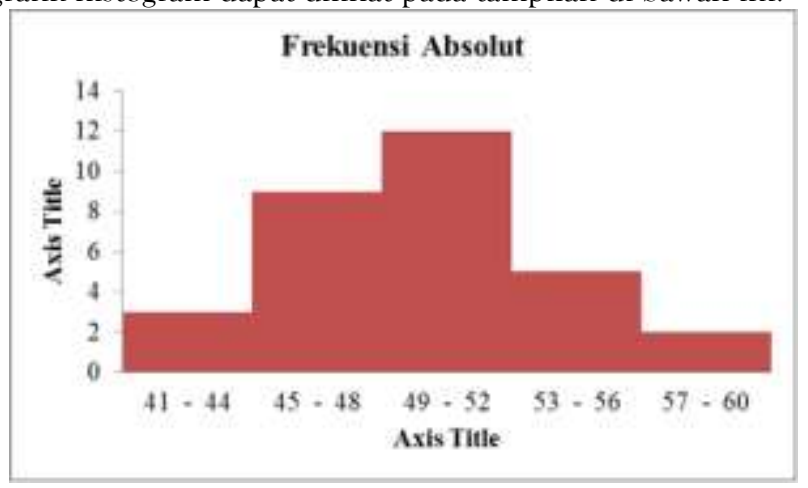

Gambar 1. Histogram Distribusi Frekuensi Skor Bimbingan Belajar

Dari data yang ada dapat dipahami bahwa secara umum bimbingan belajar tergolong pada tingkat sedang.

Data variabel kemandirian belajar dalam penelitian ini dikumpulkan melalui penyebaran kuesioner kepada 31 orang responden. Pertanyaan yang diajukan dalam variabel berjumlah 23 item pertanyaan. Distribusi skor jawaban responden menyebar dari skor terendah 51 dan skor tertinggi 68. Berdasarkan perhitungan dari disatribusi data, diperoleh rata-rata sebesar 59,03 dan standar deviasi (SD) 4,340. Perhitungan ini menunjukkan rata-rata dan median yang tidak jauh berbeda. Hal ini memberikan indikasi bahwa skor data variabel kemandirian belajar cenderung berdistribusi normal. Sutrisno Hadi menyebutkan bahwa, harga rata-rata yang tidak jauh berbeda dengan harga median, dapat dipakai sebagai ukuran gejala pusat untuk kepentingan analisis selanjutnya (Sutrisno Hadi, 1998:5155). Kesimpulan serupa juga diperoleh jika data yang sama dianalisa melalui uji skewness $(-0,112)$ dan kurtosis (0,234), dan ternyata jauh berada dibawah angka standar yang ditetapkan angka tiga. Hasil perhitungan ini memberikan indikasi bahwa data variabel kemandirian belajar berdistribusi normal. Sebaran skor bimbingan belajar guru disajikan dalam daftar distribusi frekuensi dengan jumlah kelas sebanyak 6 dan panjang kelas 3. Deskripsi data secara lengkap dapat dilihat pada lampiran tesis ini. Gambaran umum variabel kemandirian belajar ini bila ditampilkan dalam bentuk grafik histogram dapat dilihat pada tampilan di bawah ini.

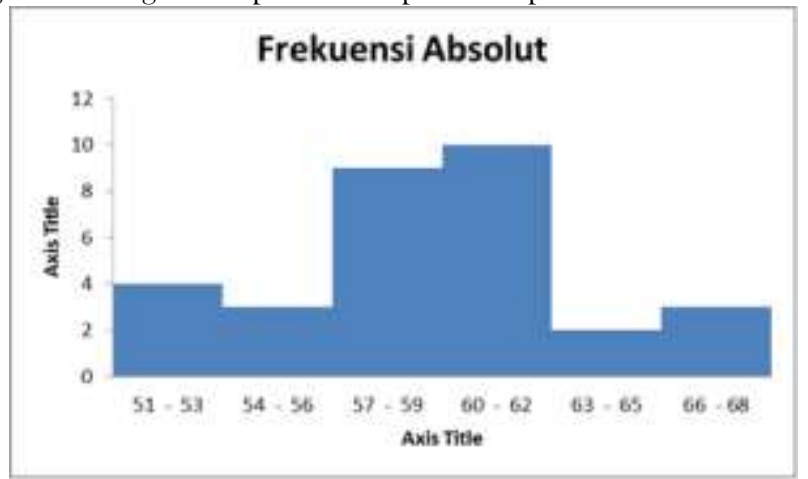

Gambar 2. Histogram Distribusi Frekuensi Skor Kemandirian Belajar

Dari data yang ada dapat dipahami bahwa secara umum kemandirian belajar tergolong pada tingkat sedang.

\section{Uji Persyaratan Analisis}

Pengolahan data kajian penelitian menggunakan pengujian statistik dengan analisis regresi linear sederhana. Namun sebelum itu, peneliti melakukan uji persyaratan analisis sehingga hasilnya dapat digunakan untuk menarik kesimpulan. Uji persyaratan yang dimaksud mencakup normalitas, homogenitas dan linieritas. Pengujian persyaratan yang pertama dilakukan adalah uji normalitas. Uji persyaratan normalitas ini dilakukan terhadap X dan Y dengan menggunakan uji Kormogorov Smirnov menggunakan bantuan Program SPSS Versi 18.00. Untuk menerima atau menolak hipotesis nol, kita bandingkan nilai signifikan $(a=0,05)$ dengan nilai signifikan yang diperoleh. Kriterianya bahwa variavel berdistribusi normal jika nilai signifikan yang diperoleh lebih besar dari $a=0,05$. Rangkuman analisis pengujian normalitas sebaran data sebagaimana tergambar pada table 1 berikut. 
Tabel 1. Uji Normalitas Dengan Kormogorv Smirnov

\begin{tabular}{|c|c|c|c|c|c|c|}
\hline & \multicolumn{3}{|c|}{ Kolmogorov-Smirnov ${ }^{a}$} & \multicolumn{3}{|c|}{ Shapiro-Wilk } \\
\hline & Statistic & $\mathrm{df}$ & Sig. & Statistic & $\mathrm{df}$ & Sig. \\
\hline Bimbingan Belajar &, 119 & 31 &, $200^{*}$ & ,979 & 31 &, 796 \\
\hline Kemandirian Belajar &, 142 & 31 &, 112 & ,957 & 31 &, 242 \\
\hline
\end{tabular}

Dari Tabel 1 dapat dilihat bahwa nilai signifikan untuk variable bimbingan belajar sebesar 0,200* dan variable kemandirian belajar sebesar 0,112. Nilai signifikan ini lebih besar dari taraf signifikan $\alpha=0,05$. Dengan demikian, dapat dikatakan bahwa masing-masing variable berdistribusi normal.

Selain data harus normal, selanjutnya dilakukan uji homogenitas varians terhadap data masing-masing variabel dengan menggunakan uji Levene. Kriterianya bahwa variavel memiliki varian yang homogen jika nilai signifikan yang diperoleh lebih besar dari $a=0,05$. Hasil perhitungan homogenitas varians skor bimbingan belajar dan kemandirian belajar siswa selengkapnya dapat dilihat pada Tabel 2 berikut.

Tabel 2. Uji Homogenitas Dengan Levene

\begin{tabular}{rrrrr}
\hline Levene Statistic & df1 & df2 & Sig. \\
\hline, 009 & & 1 & 60 &, 925 \\
\hline
\end{tabular}

Dari Tabel 2 di atas, maka varians skor bimbingan belajar dan kemandirian belajar siswa yang diperoleh adalah lebih besar dari taraf signifikansi $\alpha=0,05(0,925>0,05)$. Selanjutnya disimpulkan bahwa bimbingan belajar dan kemandirian belajar siswa adalah homogen.

Untuk mengetahui linier atau tidaknya hubungan setiap variable, maka peneliti melakukan kajian uji linieritas variable eksogen yaitu bimbingan belajar dan kemandirian belajar siswa. Artinya, dalam kajian ini dapat disimpulkan bahwa apabila dibuat scatter diagram dari nilai setiap variable, yaitu bimbingan belajar dan kemandirian belajar siswa apabila ditarik garis lurus akan tergambar pancaran titik-titik dari kedua nilai variable tersebut. Selanjutnya, dengan bantuan Program SPSS Versi 18.00 dapat diketahui apakah terdapat pengaruh variable bimbingan belajar dan kemandirian belajar siswa sehingga pada konsepsi ini dapat ditentukan apakah variable penelitian dikategorikan linier atau tidak linier. Sedangkan untuk menguji linieritas data peneliti menggunakan rumus statistic, yaitu uji F. Untuk perhitungan uji $\mathrm{F}$ tersebut peneliti menggunakan bantuan SPSS Versi 18.00 sehingga dapat ditarik kesimpulan hasil uji $\mathrm{F}$ yaitu apabila bila $\mathrm{F}_{\text {hitung }}$ lebih kecil dari $\mathrm{F}_{\text {tabel }}$ maka data dinyatakan mengikuti model regresi linier, begitu pula sebaliknya. Berdasarkan hasil analisis maka dapat digambarkan bahwa nilai signifikansi yang diperoleh sebesar 0,000. Karena signifikansi kurang dari 0,05 maka dapat disimpulkan bahwa antara bimbingan belajar dan kemandirian belajar siswa terdapat hubungan yang linier. Rangkuman hasil perhitungan linieritas dapat dilihat pada table 3 berikut:

Tabel 3. Uji Linieritas Antara Bimbingan Belajar Dan Kemandirian Belajar Siswa

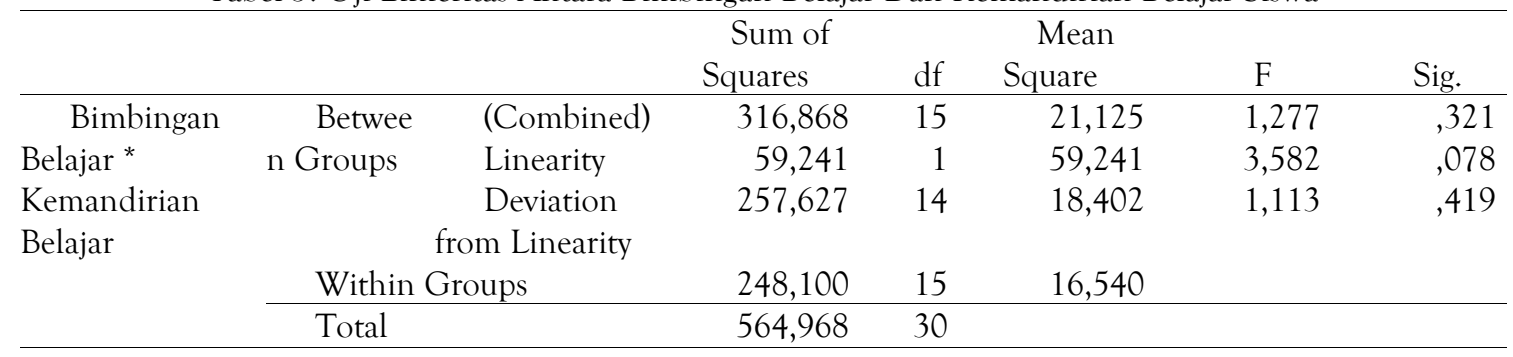

Berdasarkan table 3 di atas bahwa hasil pengujian linieritas pengaruh setiap variable penelitian yang dilakuka menunjukkan bahwa terdapat hubungan linieritas antar variable yang satu dengan yang lainnya. Setelah memenuhi uji persyaratan tersebut, maka langkah selanjutnya adalah melakukan uji regresi linear sederhana.

\section{Pengujian Hipotesis}

Hipotesis pertama yang dimunculkan dalam penelitian adalah "Ada pengaruh bimbingan belajar terhadap kemandirian belajar siswa SD Negeri 025 Rambah Hilir Kabupaten Rokan Hulu Provinsi Riau”. Berdasarkan hipotesis penelitian tersebut, maka hipotesis nol (Ho) yang diuji adalah "tidak ada pengaruh bimbingan belajar terhadap kemandirian belajar siswa SD Negeri 025 Rambah Hilir Kabupaten Rokan Hulu Provinsi Riau”. Berikut akan disajikan hasil analisis dengan bantuan program SPSS 18.00. 
Tabel 4 Model Summary ${ }^{\mathrm{b}}$

\begin{tabular}{rrrrr}
\hline Model & R & R Square & $\begin{array}{l}\text { Adjusted R } \\
\text { Square }\end{array}$ & $\begin{array}{r}\text { Std. Error } \\
\text { of the Estimate }\end{array}$ \\
\hline 1 &, $324^{\mathrm{a}}$ &, 105 &, 074 & 4,176 \\
\hline
\end{tabular}

Berdasarkan tabel 4 diperoleh infromasi bahwa besarnya persentase pengaruh variabel bebas terhadap variabel terikatnya. Besar koefisien determinasi adalah 0,105 mengandung pengertian bahwa pengaruh variabel bimbingan belajar terhadap kemandirian belajar siswa adalah 32,4\%. Sedangkan 67,6\% dipengaruh oleh variabel lain.

Tabel 5. ANOVA ${ }^{\mathrm{b}}$

\begin{tabular}{llrrrrc}
\hline & Model & \multicolumn{1}{c}{$\begin{array}{c}\text { Sum of } \\
\text { Squares }\end{array}$} & \multicolumn{1}{c}{ df } & Mean Square & F & \multicolumn{1}{c}{ Sig. } \\
\hline 1 & Regression & 59,241 & 1 & 59,241 & 3,397 &, $007^{\mathrm{a}}$ \\
& Residual & 505,727 & 29 & 17,439 & & \\
\hline & Total & 564,968 & 30 & & & \\
\hline
\end{tabular}

a. Predictors: (Constant), Bimbingan Belajar

b. Dependent Variable: Kemandirian Belajar

Berdasarkan tabel 5 diperoleh informasi bahwa nilai F hitung adalah 3,397 sedangkan besarnya signifikansinya 0,000. Nilai signifikansi ini lebih kecil dari 0,007. Dengan demikian, $\mathrm{H}_{0}$ ditolak dan Ha diterima. Artinya, variasi nilai variabel bimbingan belajar dapat menjelaskan variasi kemandirian belajar siswa.

Tabel 6 Coefficients ${ }^{\mathrm{a}}$

\begin{tabular}{|c|c|c|c|c|c|c|}
\hline \multirow{3}{*}{\multicolumn{2}{|c|}{ Model }} & \multicolumn{5}{|c|}{ Standardized } \\
\hline & & \multicolumn{2}{|c|}{ Unstandardized Coefficients } & \multirow{2}{*}{$\frac{\text { Coefficients }}{\text { Beta }}$} & \multirow[b]{2}{*}{$\mathrm{t}$} & \multirow[b]{2}{*}{ Sig. } \\
\hline & & $\mathrm{B}$ & Std. Error & & & \\
\hline 1 & (Constant) & 42,529 & 8,985 & & 4,733 &, 000 \\
\hline & Bimbingan & ,332 & , 180 & ,324 & 1,843 & ,007 \\
\hline \multicolumn{2}{|c|}{ Belajar } & & & & & \\
\hline
\end{tabular}

a. Dependent Variable: Kemandirian Belajar

Berdasarkan tabel 6 diperoleh informasi bahwa kolom B pada constant (a) adalah 42,529 sedangkan nilai bimbingan belajar (b) adalah 0,332. Besarnya nilai t dapat dijadikan petunjuk untuk mengetahui apakah variabel bimbingan belajar berpengaruh terhadap kemandirian belajar siswa. Bila $\mathrm{H}_{0}$ ditolak $(\mathrm{sig} .<0,05)$ berarti berpengaruh, kalau $\mathrm{H}_{0}$ diterima (sig. > 0,05) berarti tidak berpengaruh. Dari tabel IV.13 diketahui besarnya nilai t tes adalah 4,733 sedangkan besarnya signifikansi 0,007 lebih kecil dari 0,05. Dengan demikian, $\mathrm{H}_{0}$ ditolak yang berarti ada pengaruh bimbingan belajar terhadap kemandirian belajar siswa di SDN 025 Rambah Hilir.

\section{PEMBAHASAN}

Penelitian yang dilaksanakan dengan menetapkan bimbingan belajar variabel bebas dan kemandirian belajar siswa sebagai variabel terikat, sungguh menarik untuk diteliti. Analisis deskriptif yang dijalankan menunjukkan bahwa kategori bimbingan belajar secara umum berada pada posisi sedang, hanya sebahagian kecil yang berada pada kategori tinggi dan rendah. Demikian pula halnya pada variabel terikat kemandirian belajar siswa, melalui analisis yang sama (deskriptif), penulis juga mendapati tingkat kemandirian belajar siswa tergolong sedang. Kenyataan ini secara umumnya mempunyai keterkaitan meskipun tidak erat antara kedua variabel yang dianalisis. Hal ini diperkuat lagi dengan hasil temuan penelitian yang menunjukkan bahwa hipotesis alternatif yang diajukan dalam penelitian ini diterima. Berikut akan diuraikan temuan yang telah dianalisis.

Temuan pertama: Semakin sering bimbingan belajar dilakukan, maka ada kecenderungan semakin tinggi pula kemandirian belajar siswa. Secara holistik variabel bebas tersebut ternyata mempunyai hubungan yang sangat signifikan dengan bimbingan belajar yang dilakukan para guru. Koefisien korelasi antara variabel bebas dan variabel terikat diperoleh sebesar 0,105 memberi makna kontribusi bimbingan belajar terhadap kemandirian belajar siswa sebesar 32,4 \%. Ini bermakna pengaruh bimbingan belajar cukup besar untuk meningkatkan kemandirian belajar siswa. Menurut Skinner, bimbingan bertujuan untuk menolong setiap individu dalam membuat pilihan dan menentukan sikap yang sesuai dengan kemampuan, minat, dan kesempatan yang ada yang sejalan dengan nilai-nilai sosialnya. (Hamalik, 2010). Dari uraian tersebut dapat disimpulkan bahwa tujuan layanan bimbingan belajar untuk mengarahkan siswa agar memiliki sikap tanggungjawab, dan mampu menggunakan potensi didalam dirinya secara maksimal. Menurut Sukardi (1983) tujuan pelayanan bimbingan belajar secara umum adalah membantu muridmurid agar mendapat penyesuaian yang baik di dalam situasi belajar, sehingga setiap murid dapat belajar dengan efesien sesuai dengan kemampuan yang dimilikinya, dan mencapai perkembangan yang optimal. 
Temuan kedua, Semakin sering bimbingan belajar dilakukan, maka ada kecenderungan semakin besar kontribusinya dalam meningkatkan kemandirian belajar siswa. Dari analaisis regresi sederhana diperoleh persamaan $\mathrm{Y}=42,529+0,332 \mathrm{X}$, dapat dijelaskan bahwa terjadi pengaruh positif yang mana apabila skor bimbingan belajar naik, maka skor kemandirian belajar siswa juga akan turut naik.

\section{SIMPULAN DAN SARAN}

\section{Simpulan}

Berdasarkan hasil penelitian bahwa bahwa bimbingan belajar memiliki rata-rata 49,68 sedangkan variabel kemandirian belajar siswa memiliki rata-rata 59,03. Selain itu, diketahui besarnya nilai t tes adalah 4,733 sedangkan besarnya signifikansi 0,007 lebih kecil dari 0,05. Dengan demikian, $\mathrm{H}_{0}$ ditolak yang berarti ada pengaruh bimbingan belajar terhadap kemandirian belajar siswa SD Negeri 025 Rambah Hilir Kabupaten Rokan Hulu Provinsi Riau. Sedangkan besar koefisien determinasi adalah 0,324 mengandung pengertian bahwa pengaruh variabel bimbingan belajar terhadap kemandirian belajar siswa adalah 32,4\%. Sedangkan 67,6\% dipengaruh oleh variabel lain.

\section{Saran}

Saran yang disampaikan adalah dengan adanya pengaruh yang signifikan tersebut, sekolah lebih memperhatikan Bimbingan Belajar dengan memberikan fasilitas dan prioritas terhadap hal yang dapat memacu Kemandirian Belajar sehingga cita-cita siswa dapat tercapai dengan lebih baik sesuai harapan yang ada. Secara umum penilaian Bimbingan Belajar hendaknya didasarkan pada sebuah tujuan yang jelas, memiliki dukungan Kemandirian Belajar agar jelas dalam mengadaptasi perubahan kurikulum pendidikan di sekolah.

\section{DAFTAR RUJUKAN}

Abu Ahmadi dan Widodo Supriyono. 2004. Pskologi Belajar (edisi revisi). Jakarta: Rineka Cipta.

Anas Sudjiono. 1986. Teknik Evaluasi Pendidikan. Yogyakarta: UD Rama.

Badudu dan Zain Sutan Mohammad. 2001. Kamus Umum Bahasa Indonesia. Jakarta: Pustaka Sinar Harapan.

Bimbingan Belajar Simbol Ketidakpercayaan terhadap Sekolah, 31 juli 2006, www.primagama.co.id/profile/profilekini.php

Burhan Bungin. 2005. Metodelogi penelitian kualitatif. Jakarta: Kencana

Dewa Ketut Sukardi. 2002. Pengantar Pelaksanaan Program Bimbingan dan Konseling di Sekolah. Jakarta: Rineka Cipta.

Muhammad Buchori. 1983. Teknik-teknik Evaluasi Dalam Pendidikan. Bandung: Jemmars.

Muhibbin Syah. 2003. Psikologi Belajar. Jakarta: PT Raja Grafindo Persada.

Nana Sudjana. 2005. Penilaian Hasil Proses Belajar Mengajar. Bandung: Remaja Rosdakarya.

Nana Syaodih Sukmadinata. 2005. Landasan Psikologi Proses Pendidikan. Bandung: PT Remaja Rosdakarya.

Oemar Hamalik. 1990. Psikologi Belajar dan Mengajar. Bandung: Sinar Baru Algensindo.

Soelastri. 2002. Menjelang Ujian Masuk PTN Perlukah Ikut Bimbingan Belajar.

Suharsimi Arikunto. 2002. Prosedur Penelitian. Jakarta: Rineka Cipta.

Sutrisno Hadi, 1998, Metodologi Penelitian, Yogyakarta: Fakultas Psikologi UGM. 